Volume 2 Nomor 2, Desember 2019

E-ISSN : 2655-7347

\title{
ANALISIS PENETAPAN PENGADILAN NEGERI SURAKARTA NO. \\ 46/PDT.P/2016/PN.SKT TERKAIT PERKAWINAN BEDA AGAMA \\ DITINJAU BERDASARKAN UNDANG-UNDANG NO. 1 TAHUN 1974
}

\author{
Alberta Felia Lokawijaya \\ (Mahasiswa Program S1 Fakultas Hukum Universitas Tarumanagara) \\ (E-mail: albertafelia@ymail.com)
}

Mulati, S.H., M.H.

(Corresponding Author)

(Dosen Fakultas Hukum Universitas Tarumanagara, Meraih Sarjana Hukum pada Fakultas Hukum Universitas Tarumanagara (1982), Magister Hukum Universitas Tarumanagara (1996)

(E-mail: $\underline{\text { mulati@fh.untar.ac.id) }}$

\begin{abstract}
In the lives of individuals in this world who have distinctive genders (people), normally have an alluring fascination between each other to have the option to live respectively. The opportunity to pick an actual existence accomplice in Indonesia doesn't have any significant bearing completely in such a case that a marriage is finished by an accomplice of various religions will cause a ton of discussion among the individuals of Indonesia. Truth be told, numerous couples need to live respectively yet are blocked by their religion. In settling on interfaith marriage applications, there are the individuals who enable union with proceed; yet some are against. Assurance of various judges causes legitimate vulnerability, this causes uneasiness for the Civil Registry office in giving marriage testaments. With the endorsement of interfaith relationships by the judges additionally lead to deviations from what has been set up by law. things that ought to be considered by made a decision in choosing interfaith relationships are good and juridical perspectives. A marriage did absolutely causes legitimate outcomes. On the off chance that relationships are led by an accomplice of various religions will cause issues, this issue is identified with the relationship of a couple, youngster status, legacy, religion embraced by kids.
\end{abstract}

Keywords: Marriage, Difference religious, due to interfaith marriages

\section{PENDAHULUAN}

\section{A. Latar Belakang}

Indonesia yang terdiri dari pulau-pulau menyebabkan adanya berbagai macam etnis budaya, maupun agama, hal ini disebabkan karena beberapa faktor yang diantaranya adalah keadaan geografis sehingga tercipta akulturasi yang beragam. Secara alami hal ini membentuk pola relasi antar agama di Indonesia dalam kehidupan bermasyarakat. Pada dasarnya manusia tercipta sebagai makhluk sosial yaitu memerlukan bantuan orang lain atau tidak dapat hidup sendirian. 
Volume 2 Nomor 2, Desember 2019

E-ISSN : 2655-7347

Dalam kehidupan manusia didunia ini yang berlainan jenis kelaminnya (laki-laki dan perempuan), adanya daya tarik menarik timbul secara alamiah antara satu dengan lainnya untuk bisa hidup bersama atau secara logis dapat dikatakan untuk membentuk suatu ikatan lahir dan batin dengan tujuan menciptakan suatu keluarga/rumah tangga yang rukun, bahagia, sejahtera, dan abadi. ${ }^{1}$

Perkawinan menurut UU No. 1 Tahun 1974 ialah hubungan antara seorang wanita dan pria yang disatukan berdasarkan Ketuhanan YME dengan adanya ikatan lahir batin sebagai suami istri dengan tujuan membentuk keluarga (rumah tangga) yang bahagia dan kekal. Perkawinan merupakan sumber dari kelahiran manusia, namun disamping itu juga merupakan tali ikatan yang melahirkan keluarga sebagai dasar kehidupan masyarakat dan negara. Dengan lahirnya suatu keluarga maka suatu peradaban manusia tercipta dengan sendirinya.

Kebebasan menentukan pasangan di Indonesia tidak berlaku absolut. Yang menjadi persoalan rumit di Indonesia adalah perkawinan yang dilaksanakan oleh pria dan wanita yang memiliki perbedaan keyakinan. Perkawinan beda agama diatur didalam UU No. 1 Tahun 1974 pasal 2 ayat (1) yang menyatakan bahwa perkawinan adalah sah, apabila dilakukan menurut hukum masing-masing agama dan kepercayaannya. Dapat disimpulkan bahwa dinyatakan sah atau tidaknya perkawinan dilihat bedasarkan perkawinan mereka dilakukan dengan hukum apa, jika tidak ditentukan oleh agama maka perkawinan mereka dapat dinyatakan bertentangan dengan hukum agama maka dinyatakan tidak sah dan tidak timbul akibat hukum dari perkawinan itu. Perkawinan yang dilakukan bertolak belakang dengan ketentuan hukum agama, maka hukum negara juga menganggap tidak sah dan tidak ada akibat hukum yang timbul dari perkawinan tersebut.

\footnotetext{
${ }^{1}$ Sutiono Usman Adji, Kawin Lari dan Kawin Antar Agama, (Yogyakarta: Liberty Yogyakarta, 1989), hal. 19.
} 
Volume 2 Nomor 2, Desember 2019

E-ISSN : 2655-7347

Indonesia disebut sebagai negara yang menerapkan pancasila dengan sila pertamanya Ketuhanan Yang Maha Esa, agama dan perkawinan memiliki persaudaraan yang erat, perkawinan bukan hanya untuk memenuhi unsur jasmani tetapi juga rohani. Artinya hanya dengan ikatan lahir perkawinan itu tidak dapat dinyatakan sebagai perkawinan namun harus beriringan dengan ikatan batin.

Supaya perkawinan diakui oleh negara perkawinan dilakukan dengan cara mendaftarkan perkawinan lalu d dicatatkan. Dua pihak yang beragama Islam, perkawinan dilaksanakan dan dicatatkan di Kantor Urusan Agama (KUA), lalu untuk pasangan yang beragama non-Islam, perkawinan dilaksanakan di Kantor Catatan Sipil. Dengan adanya bukti pencatatan perkawinan secara hukum maka perkawinan tersebut dinyatakan sah oleh Negara. Tidak akan ada masalah jika perkawinan dilakukan oleh pasangan yang meyakini agama yang sama. Sebagaimana contoh apabila pasangan beragama Islam melakukan perkawinan secara hukum islam maka secara hukum negara dianggap sah dan telah sesuai dengan aturan yang telah ditetapkan hukum Islam. Demikian juga bagi sesama umat Katolik yang melakukan perkawinan dengan aturan agama Katolik maka perkawinan tersebut juga disebut sah secara agama maupun secara hukum.

Dari segi agama, pelaksanaan suatu perkawinan merupakan suatu perintah karena manusia diciptakan kedunia dengan memiliki pasangan hidup maka sudah seharusnya dan sudah menjadi kelaziman apabila seorang wanita dan pria hidup bersama didalam perkawinan. Perkawinan merupakan hal yang penting, selain keperluan biologis antara pasangan, akan tetapi dari perkawinan itu diharapkan menghasilkan generasi yang sehat lahir dan batin.

Status perkawinan beda agama sering kali diperdebatkan, namun belum ada upaya yang jelas untuk menangani perihal ini. Dua insan yang hendak melakukan perkawinan beda agama di Indonesia, sebagian dari mereka memilih untuk memberikan permohonan ke Pengadilan Negeri. 
Volume 2 Nomor 2, Desember 2019

E-ISSN : 2655-7347

Penetapan yang dikeluarkan hakim dari berbagai daerah berbeda-beda, ada yang menyetujui namun ada juga yang menolak. Hal ini tidak bisa dipandang remeh, karena dapat menimbulkan ketidakpastian hukum dan diperlukan kajian hukum secara tegas untuk permasalahan perkawinan beda agama.

Pernyataan mengenai cinta mengalahkan segalanya menyebabkan banyak dua insan dengan agama berbeda tetap berusaha melakukan perkawinan, akibatnya banyak dari pasangan melakukan perkawinan tidak sesuai dengan aturan hukum yang berlaku, sehingga banyak pasangan memilih menjalankan kehidupan bersama atau dibilang kumpul kebo yang didasari adanya perbedaan agama atau kepercayaan dan hubungan tersebut hanya berlandaskan komitmen yang dibuat oleh kedua pihak, tetapi munculah permasalahan ketika komitmen yang dibuat tidak berjalan dengan baik dan menimbulkan akibat hukum yaitu terganggunya ketentraman dalam berumah tangga dan tidak ada peran agama dalam menanggulangi permasalahan yang muncul.

Oleh karena itu, jika perkawinan beda agama tetap dilakukan dampak yang dirasakan yaitu menimbulnya akibat baik secara psikologi ataupun secara hukum bagi pasangan beda agama dan tentunya buah hati yang terlahir dari perkawinan itu.

Larangan perkawinan beda agama ini tidak dialami oleh pasangan beda agama antara Aloysia Vettyana Ratnawati yang beragama Katolik dengan Dandi Ferdian yang beragama Islam. Pasangan ini semula mendaftarkan diri untuk perkawinan mereka dapat dicatatkan di Catatan Sipil namun ternyata terjadi penolakan, dan akhirnya membawa mereka untuk mengajukan permohonan perkawinan beda agama ke Pengadilan Negeri Surakarta. Dalam hal ini hakim yang menangani mengabulkan perkawinan mereka dengan pertimbangan adanya kekosongan hukum, hal ini bertolak belakang dengan apa yang sudah diatur oleh UU Perkawinan.

Berdasarkan uraian diatas, penulis tertarik untuk membahasnya dalam skripsi ini dengan judul “Analisis Penetapan Pengadilan Negeri Surakarta 
Volume 2 Nomor 2, Desember 2019

E-ISSN : 2655-7347

No. 46/Pdt.P/2016/Pn.Skt Terkait Perkawinan Beda Agama Ditinjau Berdasarkan Undang-Undang No. 1 Tahun 1974”.

\section{B. Permasalahan}

Berdasarkan yang sudah dijelaskan dilatar belakang, adapun permasalahan yang penulis teliti yaitu :

1. Bagaimana dasar pertimbangan hakim dalam mengabulkan permohonan ijin perkawinan beda agama?

2. Bagaimana akibat hukum dari perkawinan beda agama?

\section{Metode Penelitian}

Penelitian hukum dilakukan untuk mencari pemecahan atas isu hukum yang timbul. ${ }^{2}$ Oleh karena itu, metode penelitian diperlukan untuk mencapai tujuan dari penelitian hukum. Penulis harus cermat dalam menentukan metode yang akan dipergunakan agar metode yang dipilih tepat dan jelas sehingga mendapatkan hasil dengan kebenaran yang dapat dipertanggungjawabkan. Berdasarkan perumusan masalah dan tujuan penelitian, maka metode penelitian yang digunakan adalah sebagai berikut:

1. Jenis Penelitian

Jenis penelitian yang digunakan dalam penelitian ini adalah penelitian hukum normatif, yaitu suatu jenis penelitian hukum yang diperoleh dari studi kepustakaan, ${ }^{3}$ dengan menganalisis suatu permasalahan hukum melalui peraturan perundang-undangan, literatur-literatur dan bahan-bahan referensi lainnya yang berhubungan dengan perkawinan beda agama.

2. Sifat Penelitian

Sifat penelitian yang digunakan dalam penelitian ini adalah deskriptif. Maksud dari penelitian yang bersifat deskriptif adalah penulis dalam upaya untuk mencapai tujuan penelitian ini, berkeinginan untuk menggambarkan

\footnotetext{
2 Peter Mahmud Marzuki, Penelitian Hukum Edisi Revisi, Cetakan ke-8, (Jakarta: Kencana Prenada Media Group, 2013), hal. 5

${ }^{3}$ Ibid, hal. 35
} 
Volume 2 Nomor 2, Desember 2019

E-ISSN : 2655-7347

atau memaparkan subjek dan objek penelitian sesuai dengan hasil penelitian yang telah dilakukan. ${ }^{4}$

3. Jenis dan Sumber Data

Sebagaimana jenis penelitian yang digunakan adalah penelitian hukum normatif, maka jenis data yang digunakan adalah data sekunder yang dilakukan dengan studi pustaka terhadap bahan-bahan hukum yaitu bahan hukum primer dan bahan hukum sekunder.

Sumber data yang digunakan antara lain:

a. Bahan Hukum Primer

Bahan hukum primer merupakan bahan hukum yang bersifat autoritatif artinya mempunyai otoritas. Bahan-Bahan hukum primer terdiri dari perundang-undangan dan putusan-putusan hakim. ${ }^{5}$ Bahan hukum primer yang digunakan dalam penelitian ini antara lain: Kitab UndangUndang Hukum Perdata; Undang-Undang No. 1 tahun 1974 tentang perkawinan; PP No. 9 Tahun 1975 tentang Pelaksanaan Undang-Undang Nomor 1 Tahun 1974 Tentang Perkawinan; Kompilasi Hukum Islam; UU No. 24 Tahun 2013 tentang Perubahan atas UU No. 23 Tahun 2006 Tentang Administrasi Kependudukan; Peraturan Presiden No. 96 Tahun 2018 tentang Persyaratan dan Tata Cara Pendaftaran Penduduk dan Pencatatan Sipil; Penetapan Pengadilan Negeri Surakarta no. 46/Pdt. P/2016/ PN.Skt.

b. Bahan Hukum Sekunder, yaitu bahan-bahan hukum yang tidak mengikat namun memberikan penjelasan mengenai bahan hukum primer, seperti rancangan undang-undang, hasil-hasil penelitian, buku, jurnal dan seterusnya. ${ }^{6}$

4. Teknik Pengumpulan Data

\footnotetext{
${ }^{4}$ Mukti Fajar dan Yulianto Achmad, Dualisme Penelitian Hukum Normatif \& Empiris, Cetakan ke-4, (Yogyakarta: Pustaka Pelajar, 2017), hal. 183

${ }^{5}$ ibid, hal. 181

${ }^{6}$ Soerjono dan Mamudji, Penelitian Hukum Normatif: Suatu Tinjauan Singkat, (Jakarta: Rajawali Pers, 2011), hal. 13
} 
Volume 2 Nomor 2, Desember 2019

E-ISSN : 2655-7347

Teknik pengumpulan data dalam penelitian hukum normatif dilakukan dengan cara studi dokumen atau bahan pustaka (library research) terhadap bahan-bahan hukum, baik bahan hukum primer, bahan hukum sekunder, maupun bahan tertier. Penelusuran bahan-bahan hukum tersebut dapat dilakukan dengan membaca, melihat, mendengarkan, maupun sekarang banyak dilakukan penelusuran bahan hukum tersebut dengan media internet. ${ }^{7}$ Selain dengan studi dokumen, pengumpulan data dalam penelitian dapat dilengkapi dengan wawancara dengan para pihak yang terkait dan narasumber (ahli hukum).

5. Teknik Penyajian Data

Dalam penelitian hukum normatif, pengolahan bahan berwujud kegiatan untuk mengadakan sistematisasi terhadap bahan-bahan hukum tertulis. Dalam hal ini pengolahan bahan dilakukan dengan cara, melakukan seleksi data sekunder atau bahan hukum, kemudian melakukan klasifikasi menurut penggolongan bahan hukum dan menyusun data hasil penelitian tersebut secara sistematis, tentu saja hal tersebut dilakukan secara logis, artinya ada hubungan dan keterkaitan antara bahan hukum satu dengan bahan hukum lainnya untuk mendapatkan gambaran umum dari hasil penelitian. ${ }^{8}$

6. Teknik Analisis Data

Teknik analisis data dalam penelitian ini adalah teknik kualitatif. Pendekatan kualitatif adalah data yang diperoleh dari penelitian kepustakaan, yang selanjutnya dianalisa secara kualitatif untuk memperoleh suatu kejelasan mengenai suatu permasalahan yang akan di teliti. Dalam melakukan penelitian, penulis harus dapat menentukan bahan hukum mana yang memiliki kualitas sebagai data dan bahan hukum mana yang tidak relevan dan tidak memiliki keterikatan dengan masalah yang diteliti. $^{9}$

\footnotetext{
${ }^{7}$ Mukti Fajar dan Yulianto Achmad, Dualisme Penelitian Hukum Normatif dan Empiris, ( Yogyakarta: Pustaka Belajar, 2010), hal. 160.

${ }^{8}$ Soerjono \& Mamudji, Op.cit.,hal. 181.

${ }^{9}$ Mukti Fajar dan Yulianto Achmad, Op.cit., hal. 192
} 
Volume 2 Nomor 2, Desember 2019

E-ISSN : 2655-7347

\section{PEMBAHASAN}

\section{A. Hasil Penelitian}

\section{Profil Kasus dan Para Pihak}

Pada kasus perbedaan agama atau kepercayaan antara Aloysia Vettyana Ratnawati yang beragama Katolik dengan Dandi Ferdian yang beragama Islam menyebabkan sulitnya melangsungkan perkawinan, awal mula pasangan ini datang ke Catatan Sipil untuk meminta perkawinan mereka dapat dicatatkan dan dilaksanakan, namun Catatan Sipil melakukan penolakan. Penolakan yang dilakukan Catatan Sipil menghantar mereka untuk mengajukan permohonan ijin perkawinan beda agama kepada Pengadilan Negeri Surakarta. Hakim yang menangani permohonan mereka, mengeluarkan penetapan yang menyatakan di setujuinya permohonan tersebut oleh Pengadilan Negeri Surakarta, dan tercatat dalam Putusan Pengadilan Negeri Surakarta No. 46/Pdt.P/2016/PN.SKT. Adanya kejanggalan atas disetujuinya permohonan ijin beda agama tersebut, karena ketetapan yang diputuskan oleh hakim bertentangan dengan UU No. 1 Tahun 1974 Pasal 2 ayat (1) yang menyatakan bahwa perkawinan adalah sah, apabila dilakukan menurut hukum masing-masing agama dan kepercayaannya itu.

\section{B. Analisis}

\section{Dasar Pertimbangan Hakim Dalam Mengabulkan Permohonan} Ijin Perkawinan Beda Agama

UU No. 1 Tahun 1974 tentang Perkawinan, didalamnya termuat inti yang menyatakan sahnya suatu perkawinan jika perkawinan dilakukan berdasarkan agama yang dianut oleh para pihak, dan di lakukan pencatatan berdasarkan Undang-undang yang berlaku.

Perkawinan merupakan hal sakral, sebagai suatu bentuk ibadah dalam agama dan kepercayaannya untuk mewujudkan kebutuhan hidup masing-masing individu. Perkawinan pada mulanya dilakukan menurut adat istiadat masing-masing pasangan, lalu kemudian 
Volume 2 Nomor 2, Desember 2019

E-ISSN : 2655-7347

dilakukan menurut kepercayaannya masing-masing. Perkawinan dikatakan sebagai suatu hal yang sakral, dengan hal ini harus dibentuk Undang-undang yang secara detail mengatur mengenai perkawinan agar melindungi para pihak yang telah melakukan perkawinan serta tidak terjadinya penyimpangan-penyimpangan norma ataupun secara agama yang terjadi di masyarakat.

Kemajuan zaman membuat pola pikir masyarakat berubah, praktis merupakan cara yang diinginkan masyarakat di era sekarang. Pola pikir yang berubah berdampak juga ke perkawinan yaitu menghalalkan segala cara untuk tetap bisa melangsungkan perkawinan walaupun sudah diketahui bahwa perkawinan itu dilarang oleh hukum agama dan Undang-undang yaitu perkawinan beda agama.

Pendapat penulis akan hal ini yaitu, perkawinan beda agama yang dilangsungkan di Indonesia sudah menjadi permasalahan yang sering dihadapi, jika suatu perkawinan beda agama yang mendapatkan penolakan dari Catatan Sipil untuk dicatatkan pernikahannya, pasangan tersebut dapat mengajukan permohonan ke Pengadilan Negeri. Perkawinan yang sesuai dengan agama dan hukum negara yaitu perkawinan yang dilakukan berdasarkan hukum Islam maka pencatatannya dilakukan di KUA, sebaliknya jika perkawinannya berdasarkan hukum non Islam, maka pencatatannya dilaksanakan di Kantor Catatan Sipil. Permohonan perkawinan beda agama tidak dilakukan di Pengadilan Agama karena Pengadilan Agama tidak dapat memberikan penetapan terkait perkara perkawinan beda agama, kewenangan yang dimiliki Pengadilan Agama yaitu memeriksa, memutus dan menyelesaikan perkara di tingkat pertama antara orangorang yang beragama Islam. Begitu juga dengan Pengadilan Negeri dalam memutus perkara perkawinan beda agama harus berdasarkan aturan hukum perkawinan yang sudah ditetapkan yaitu tidak mengeluarkan penetapan yang menyetujui perkawinan beda agama. Menurut penulis, perkawinan beda agama di Indonesia tidak dapat di 
Volume 2 Nomor 2, Desember 2019

E-ISSN : 2655-7347

toleransi lagi, tidak boleh dilakukan adanya dispensasi perkawinan beda agama, karena sudah ada peraturan yang mengatur bahwa hal tersebut dilarang. Jika dalam hal hakim memutuskan perkara tidak sesuai dengan peraturan yang sudah ditetapkan, maka hakim seharusnya mendapatkan sanksi. Perkawinan beda agama ini banyak menimbulkan pro dan kontra karena penetapan hakim yang berbedabeda, ada yang menyetujui namun ada juga yang menolak, maka dari itu menyebabkan tidak adanya kepastian hukum. Hakim mempunyai kebebasan dalam memberi putusan, kebebasan dalam memutuskan suatu perkara ini tidak boleh terlepas dari Undang-undang yang sudah ada. Jika memang menurut hakim ada kekosongan hukum dan berdasarkan rasa keadilan maka hakim boleh memutuskan dengan pertimbangan-pertimbangan yuridis. Namun jika aturan itu sudah jelas tertera dan diatur maka hakim tidak boleh memutuskan suatu perkara dengan alasan adanya kekosongan hukum.

Pendapat penulis ini diperkuat dengan pendapat yang dikemukakan oleh Ketua Pengadilan Agama Kab. Bolaang Mongondow, H. Ahmad Fernandes S.Ag. M.Sy. yang menyatakan Pengadila Agama(PA) tidak dapat memberikan penetapan terkait perkara perkawinan beda agama, kewenangan yang dimiliki PA yaitu memeriksa, memutus dan menyelesaikan perkara di tingkat pertama antara orang-orang yang beragama Islam. Begitu juga dengan Pengadilan Negeri dalam memutus perkara perkawinan beda agama harus berdasarkan asas perkawinan yang sudah ditetapkan yaitu tidak mengeluarkan penetapan yang menyetujui perkawinan beda agama. Hal ini di Indonesia tidak dapat di akomodir lagi, tidak boleh dilakukan adanya dispensasi perkawinan beda agama, karena sudah ada peraturan yang mengatur bahwa hal tersebut dilarang. Jika dalam hal hakim memutuskan perkara tidak sesuai dengan peraturan yang sudah ditetapkan, maka hakim mendapatkan sanksi. 
Volume 2 Nomor 2, Desember 2019 E-ISSN : 2655-7347

H. Ahmad Fernandes S.Ag. M.Sy selaku ketua Pengadilan Agama Kab. Bolaang Mongondow juga yang menyatakan penetapan hakim yang berbeda-beda ada yang menolak dan ada yang menerima hal ini dapat menyebabkan lemahnya hukum dan tidak memberi efek jera bagi masyarakat. Penulis setuju dengan pendapat beliau karena penetapan hakim yang berbeda pada kasus yang secara konkrit sama menyebabkan adanya penyimpangan terhadap undang-undang, khususnya penyimpangan terhadap agama. Karena perkawinan dilangsungkan tidak hanya berdasarkan adanya rasa cinta namun juga harus diiringi dengan visi dan misi dalam beragama yang sama agar dalam menjalankan kehidupan berumah tangga tidak terjadi perbedaan pendapat yang berlebihan. Sebagai negara yang memegang prinsipprinsip hukum, perkawinan dapat dinyatakan sah dan timbul akibat hukum dari perkawinan jika perkawinan itu dilaksanakan dengan taat hukum atau sesuai dengan apa yang telah diatur oleh Undang-undang.

Penulis berpendapat bahwa jika memang pasangan perkawinan beda agama tetap bersikukuh melakukan perkawinan, sebaiknya perkawinan dilakukan di Luar Negeri sesuai dengan Negara yang mengeluarkan peraturan bahwa perkawinan beda agama boleh dilangsungkan di Negara tersebut. Hal ini merujuk pada Pasal 56 UU Perkawinan ayat 1 yang menyatakan Perkawinan yang dilangsungkan diluar negeri antara dua orang WNI atau seorang WNI dengan WNA adalah sah bilamana dilakukan menurut hukum yang berlaku di negara dimana perkawinan itu dilangsungkan dan bagi WNI tidak melanggar ketentuan-ketentuan UU ini. Perkawinan yang dilaksanakan di luar negeri ini harus dicatatkan pada perwakilan RI, lalu perkawinan tersebut diterbitkan kutipan akta perkawinan. Setelah kembalinya pasangan tersebut ke Indonesia, suami istri ini wajib melaporkan perkawinannya ke Dinas Kependudukan dan Catatan Sipil paling lambat 30 hari setelah pasangan itu tiba di Indonesia. Pendapat penulis didukung dengan pendapat Hakim Pengadilan Negeri Ngawi, Ricky 
Volume 2 Nomor 2, Desember 2019

E-ISSN : 2655-7347

Fardinand, S.H yang menyebutkan ada cara yang bisa ditempuh oleh pasangan beda agama agar perkawinannya dapat dilangsungkan yaitu perkawinan dilakukan di luar negeri.

Orang dengan keuangan yang memadani, tidak menjadi hal yang merumitkan untuk melakukan perkawinan di Negara lain, namun tidak dengan keadaan ekonomi yang pas. Perkawinan beda agama yang dilakukan dengan perpindahan agama, berarti terjadi penyelundupan hukum, kenyataannya yang terlihat hanya untuk mengelabuhi secara hukum dengan ketentuan dalam UU Perkawinan.

Hakim dalam menyetujui permohonan izin perkawinan beda agama No. 46/Pdt.P/2016/PN.Skt, penulis memiliki rasa tertarik untuk meneliti lebih dalam. Dalam menjatuhkan putusannya terkait kasus perkawinan beda agama, hakim menyetujui dengan pertimbangan bahwa terjadi kekosongan hukum, dengan alasan tidak ada aturan jelas terkait hal ini. Dan lain hal, tidak dimuat secara tegas tentang perkawinan beda agama di dalam aturan yang berlaku sehingga terjadilah kekosongan hukum. Dalam penetapan tersebut, masingmasing pemohon memiliki dua agama yang berlainan. Berarti ada dua manusia dengan agama yang berlainan. Berdasarkan putusan tersebut, penulis berpendapat bahwa hakim saat menjatuhkan putusannya tidak memahami mengenai pasal 2 ayat (1) UU Perkawinan dengan inti bahwa perkawinan dilakukan berdasarkan agamanya masing-masing. Dari aturan ini dapat terlihat suatu permasalahan perkawinan adalah kewenangan yang dimiliki oleh suatu lembaga agama, yangmana tiap agama baik agama Islam atau Katolik tidak menyetujui atau menentang degan kuat adanya perkawinan beda agama dan juga suatu perkawinan adalah semata-mata perkawinan berdasarkan aturan suatu agama masing-masing di Indonesia, dengan ini perkawinan bertentangan dengan hal agama, maka kawin itu disebutkan tidak sah dan tidak memunculkan akibat hukum sbagai ikatan perkawinan yang sah. 
Volume 2 Nomor 2, Desember 2019 E-ISSN : 2655-7347

Ditakutkan perkawinan dua insan dinyatakan tidak berlaku, dan diantara kedua insan dinyatakan sebagai suami istri yang tetap berbeda agama, di pandang secara agama ini sebagai perbuatan yang tidak halal, dan apa yang diperbuatnya sama halnya dengan perzinahan. Jika nanti para pihak ini mempunyai buah hati, maka akan berdampak kepada kedudukan anak. Seperti yang dikemukakan oleh Ketua Dinas Kependudukan dan Catatan Sipil, Drs. Sugeng, MSi yaitu mengenai status anak bagi pasangan beda agama, pihak Catatan Sipil tidak bisa mengeluarkan akta kelahiran, dapat mengeluarkan akta kelahiran dengan catatan bahwa yang tertera dalam akta perkawinan hanya ibu kandungnya jadi dianggap bahwa anak tersebut hasil luar kawin karena perkawinannya yang tidak sah.

Menurut pendapat penulis, tidak satupun agama yang mengijinkan umatnya untuk melakukan perkawinan dengan tata cara perkawinan agama lain. serta juga melarang adanya perkawinan antar agama. Berdasarkan keputusan Fatwa Majelis Ulama Indonesia Nomor : 04/MUNAS VII/MUI/8/2005 tentang Perkawinan Beda Agama, bahwa Perkawinan beda agama adalah haram dan dinyatakan tidak sah, dan perkawinan laki-laki Muslim dengan wanita ahli kitab menurut Qaul Mu’tamad adalah haram dan tidak sah.

Inti dari penetapan perkawinan menurut Pasal 1 UU No. 1 Tahun 1974 perkawinan adalah dengan berlandaskan Ketuhanan YME suatu pernikahan antara pria dan perempuan diikuti kekuatan lahir batin diantara mereka untuk tercipta keluarga yang penuh kebahagiaan. Perkawinan harus tidak bertolak belakang dengan yang Maha Kuasa, hal ini terlihat dari yang diajarkan agama para pihak. Jika sudah dinyatakan bahwa perkawinan antar agama dilarang maka perkawinan yang dilakukan oleh pihak-pihak yang berbeda keyakinan dinyatakan tidak sah menurut kepercayaan atau agama.

Dalam menetapkan suatu Permohonan untuk melaksanakan perkawinan beda agama, menjadi hal yang penting yaitu hakim 
Volume 2 Nomor 2, Desember 2019

E-ISSN : 2655-7347

dilarang keras untuk menolak suatu perkara yang diajukan kepadanya, apa lagi dengan alasan tidak ada aturan yang mengaturnya. Beberapa aspek menurut penulis yang dijadikan pertimbangan dan harus diperhatikan seorang hakim dalam menjatuhkan putusan permohonan izin kawin beda agama, yaitu :

a. Aspek Khusus

Aspek khusus merupakan aspek dasar sebagai pertimbangan dalam menjatuhkan putusan permohonan izin kawin beda agama, aspek moral sebagai salah satu yang termasuk dalam aspek khusus.

Apabila dilihat dari sisi biologis (kebutuhan seksual) seseorang, kebutuhan tersebut akan tersalurkan dengan dilaksanakannya perkawinan menurut norma kebiasaan di masyarakat, hubungan biologis dipandang halal jika dilaksanakan seorang pria dan wanita yang sah terkunci didalam satu perkawinan. Apabila pengadilan tidak mengabulkan permohonannya untuk melangsungkan pernikahan dengan pasangannya yang berbeda agama dapat menimbulkan dampak buruk yang akan menjerumuskan seseorang pada kemaksiatan seperti perzinahan dan kumpul kebo. Kondisi ini dapat menimbulkan rasa malu bagi pihak keluarga. Akibatnya, pasangan zinah dan kumpul kebo ini tidak memiliki rasa ketenangan dalam menjalankan kehidupannya karena adanya sanksi sosial dari masyarakat sekitarnya. Oleh karena itu, dengan dikabulkannya permohonan izin untuk menikah, maka legalitas ikatan perkawinannya di mata hukum dan masyarakat akan terlindungi. Dengan demikian, izin perkawinan digunakan sebagai solusi yang tepat untuk menjunjung tinggi martabat seseorang dalam masyarakat dari pada hanya mengadakan hubungan pernikahan diluar hukum dan agama yang menimbulkan ikatan hubungan pernikahan yang tidak jelas, sehingga tidak mendapatkan perlindungan hukum dari negara.

b. Aspek Umum 
Volume 2 Nomor 2, Desember 2019

E-ISSN : 2655-7347

Aspek umum sebagai aspek pendukung dalam penetapan untuk memberikan pertimbangan. Aspek umum meliputi:

\section{1) Aspek Kemanusiaan}

Apabila pasangan sudah melakukan hubungan zinah atau kumpul kebo dan mengakibatkan kehamilan bagi calon istrinya, oleh Hakim dapat dijadikan pertimbangan dalam memutus perkara perkawinan ini. Dengan dikabulkannya permohonan, hak-hak seorang anak atas orang tuanya, akan terpenuhi dan terlindungi. Anak yang dilahirkan akan mendapatkan status yang jelas sehingga hak-hak keperdataannya dijamin oleh negara. Sebaliknya, apabila terjadi penolakan terhadap permohonan izin perkawinan beda agama oleh pihak pengadilan, hukum keperdataan saja yang akan dimiliki anak dari sang ibu. Anak tersebut dikemudian hari akan mengalami kesulitan untuk menuntut kewajiban yang harus dipenuhi ayah kandungnya dan memperoleh apa yang seharusnya menjadi hak-haknya.

\section{2) Aspek Normatif}

Dalam memberikan penetapan, hakim mempertimbangkan aturanaturan hukum yang berlaku, yakni seperti aturan-aturan yang terdapat di dalam perundang-undangan dan sumber hukum lainnya.

Dalam kasus yang menjadi bahan studi penulis ini, hakim mendasarkan putusannya atas pertimbangan-pertimbangan sebagaimana disebutkan pada hasil penelitian, sebagai berikut :

a) Bahwa UU No. 1 Tahun 1974 tidak memuat satupun penentuan yang berisi jika perbedaan agama diantara pasangan calon suami dan istri menjadi sebuah tolakan didalam sebuah perkawinan, dimana mengenai ini searah dengan Pasal 27 Undang-Undang Dasar 1945 yang menentukan jika seluruh warga negara diiringi dengan kedudukannya pada hukum, memuat di dalamnya persamaan hak asasi untuk menikah dengan sesama warga negara sekalipun dengan menganut agama yang berbeda 
Volume 2 Nomor 2, Desember 2019

E-ISSN : 2655-7347

dan selama oleh Undang-undang tidak dikukuhkan bahwa perbedaan keyakinan dan atau kepercayaan ditetapkan sebagai sebuah larangan untuk melangsungkan perkawinan, asas tersebut berjalan sepemikiran dengan Pasal 29 UUD 1945 tentang tetap dijamin hak setiap warga negara oleh negara yang sudah merdeka untuk dapat memeluk agama.

b) UU No. 1 Tahun 1974 dinyatakan tidak diatur nya suatu peraturan mengenai perkawinan beda agama yang mana perkawinan lebih dipertegas dengan adanya putusan Mahkamah Agung RI No : 1400 K/Pdt/1986 tanggal 20 Januari 1989 yang berbunyi : "Bahwa perbedaan agama dari calon suami istri tidak merupakan larangan perkawinan bagi mereka”.

c) Fakta dari permohonan tersebut yaitu kedua pemohon menganut agama yang berbeda.

d) UU No. 1 Tahun 1974 maupun dalam peraturan pelaksanaannya No. 9 Tahun 1975 dinyatakan tidak ada disebutkan satupun aturan mengenai tata cara melakukan perkawinan orang yang memiliki agama yang berlainan.

e) Perkawinan yang dilangsungkan para pihak yang menganut agama yang berbeda sampai saat ini dikatakan belum tercipta peraturannya berarti adanya kekosongan hukum.

Dilihat hal yang berkaitan dengan putusan tersebut, dapat dinyatakan bahwa perkawinan yang berbeda agama bisa melakukan perkawinannya dengan didaftarkannya perkawinan itu ke Kantor Catatan Sipil untuk dilangsungkannya perkawinan.

Walaupun MA telah mengatur seperti itu didalam putusannya, dilihat berdasar Pasal 21 UU Perkawinan, pihak Kantor Catatan Sipil masih dapat mengemukakan jika suatu perkawinan tidak bisa berlangsung dan dicatatkan jika melanggar ketentuan Undang-undang 
Volume 2 Nomor 2, Desember 2019

E-ISSN : 2655-7347

No. 1 Tahun 1974. Jika kedapatan bahwa perkawinan tersebut memang melanggar, maka Kantor Catatan Sipil dapat mengajukan dan mengeluarkan surat penolakan untuk mencatatkan perkawinan tersebut secara tertulis yang kemudian surat penolakan tersebut dapat diajukan ke Pengadilan yang berikutnya dapat di putuskan apa benar penolakan dari Catatan Sipil.

Dengan demikian dapat dikatakan bahwa Hakim Pengadilan Negeri Surakarta dalam mengambil keputusan mendasarkan pertimbangan-pertimbangannya pada aspek moral dan normatif. Hal ini terlihat dari dikabulkannya permohonan izin perkawinan beda agama antara Pemohon yang beragama Katolik dan calon suami yang beragama Islam. Hakim Pengadilan Negeri Surakarta dalam memutus perkara mempertimbangkan legalitas hubungan antara Pemohon dengan calon suaminya berkaitan dengan dijaminnya hak seseorang oleh negara untuk memeluk agama dan kepercayannya mereka serta adanya kesamaan hak asasi untuk dapat melangsungkan perkawinan dengan sesama warga negara meskipun adanya perbedaan agama, dan aspek normatif yang dijadikan pertimbangan Hakim paling mendasar adalah Yurisprudensi Mahkamah Agung Republik Indonesia No. 1400 K/Pdt/1986 tanggal 20 Januari 1989.

\section{Akibat Hukum Dari Perkawinan Beda Agama}

Jika perkawinan dilakukan pastinya hal itu dapat memunculkan akibat hukum dan jika perkawinan tersebut berbeda agama pastinya akan timbul masalah. Masalah yang dihadapi pasagan perkawinan beda agama menyangkut hubungan dari suami istri dan akibat yang dihadapi anak-anak yang dihasilkan dari pernikahan mereka.

Penulis berpendapat mengenai akibat hukum dengan membagi membagi akibat hukum suatu perkawinan beda agama menjadi dua bagian yaitu :

a. Aspek Psikologi 
Volume 2 Nomor 2, Desember 2019 E-ISSN : 2655-7347

Aspek psikologi yang termasuk antara lain seperti menipisnya hubungan rumah tangga yang telah disatukan sejak lama. Kehidupan rumah tangga menjadi memudar yang diakibatkan karena bedanya visi dan iman antara suami dan istri, perbedaan agama pada awal masa pacaran dan awal perkawinan masih dianggap biasa dan bisa diatasi, tetapi dengan berjalannya waktu akan terjadi jarak antara keduanya dimana ada keintiman yang semakin hari semakin redup. Saat suami istri memasuki usia lanjut maka yang dicari adalah kebahagiaan spiritual yang sumbernya dari keharmonisan keluarga yang didasari oleh iman dan tradisi keagamaan, dan saat hal itu tidak terpenuhi dan tercapai maka rasa kesepian semakin menguat sehingga keharmoisan keluarga menjadi buruk dan berlangsung tanpa tujuan.

Tujuan suami istri dalam berumah tangga tidak tercapai karena adanya perbedaan keyakinan antara keduanya, dalam hal ini agama itu ibarat sebagai pakaian yang kita gunakan sehari-hari dan melekat dalam kehidupan suami dan istri dalam berumah tangga.

Pada saat suami istri melakukukan kewajiban dan kebiasaan dalam ajaran agama nya masing-masing dan tanpa didampingi oleh pasangan atau anaknya, karena dalam setiap agama memiliki ritual yang berbeda yang harus di pegang dengan kokoh dalam kehidupan keluarga, misalnya pelaksanaan salat berjamaah dalam keluarga muslim atau pada saat bulan puasa yang akan terasa baik dan indah ketika dilakukn secara bersama-sama dengan seluruh keluarga dan akan sulit untuk diwujudkan saat adanya kehidupan suami istri beda agama sehingga kenikmatan dan kebahagiaan yang awalnya tersa sempura dan nyaman akan semakin meredup dan keharmonisan menjadi hilang dalam berkeluarga. Dalam hal 
Volume 2 Nomor 2, Desember 2019 E-ISSN : 2655-7347

ini perkawinan satu agama tidak berarti terbebas dari masalah yang akan muncul pada saat masa perkawinan dijalankan.

Pengaruh terhadap anak yaitu karena adanya perbedaan agama oleh orang tuanya sehingga anak akan sangat dirasakan dan di indonesia sendiri agama sangat dipandang serius dalam perkawinan apalagi perkawinan beda agama. Dalam hal ini akan timbul keinginan ayah atau ibunya dalam mempengaruhi anak dalam memilih keyakinan sehingga disatu sisi mengakibatkan kebingungan kepada anak dan disisi lain menjadikan anak tersebut menjadi kritis dan lebih dewasa. Pengaruh orang tua agar anaknya mengikuti keyakinan yang dianut oleh salah satu orang tuanya seperti seorang ayah yang beragama islam dia ingin anaknya menjadi muslim dan ibu nya beragama Kristen dia ingin anaknya memeluk agama Kristen.

Pasangan yang berbeda agama berharap bahwa suatu saat pasangannya akan berpindah keyakinan mengikutin keyaakinan suami atau istrinya suatu saat nnti, tetapi harapan tersebut belum tentu akan terwujud dan malah menimbulkan perselisihanperselisihan apabila tidak ada toleransi dan kesepakatan antara keduanya.

Rumah tangga yang awalnya dirakit dengan penuh cinta, lama kelamaan akan memudar akibat dari perbedaan keyakinan. Perbedaan keyakinan disini luas maknanya, salah satunya adalah perbedaan visi yang agama sudah tanamkan meskipun tujuannya sama untuk menjalankan kehidupan yang baik seturut dengan firmanNya. Seperti halnya seorang suami sebagai kepala keluarga yang beragama Islam akan melaksanakan umroh atau naik haji, alangkah bahagianya bagi seorang suami jika istri dan anakanaknya ikut bersamanya. Maka dari itu, kewajiban yang harus dilaksanakan oleh setiap pasangan suami istri yang membina rumah tangga yaitu saling melengkapi dan sesuai dengan ketentuan dalam 
Volume 2 Nomor 2, Desember 2019

E-ISSN : 2655-7347

UU Perkawinan No. 1 Tahun 1974 pasal 33 mengatakan "suami istri wajib saling cinta-mencintai hormat-menghormati, setia dan memberi bantuan lahir batin yang satu kepada yang lain”. Masalah baru juga akan dihadapi apabila perkawinan tersebut sudah dikaruniai buah hati, tentunya akan berpengaruh terhadap mental sang anak. Berebut pilihan antara suami dan istri untuk menentukan dengan siapa anaknya mengikuti agama yang diyakini, hal ini menjadi beban untuk anak dalam memilih dan menjalani agama yang sudah ditentukan. Apabila perkawinan tersebut menimbulkan permasalahan-permasalahan yang semakin melebar dan tidak ditemukan jalan keluar dari keduanya hal ini dapat menimbulkan perceraian.

b. Aspek Yuridis

Yang termasuk dari aspek yuridis yaitu pertama mengenai keabsahan dari suatu perkawinan beda agama. Menurut UU Perkawinan, perkawinan dinyatakan sah jika berdasarkan agama yang termuat dalam pasal 2 ayat (1). Dilihat berdasarkan pasal itu, dapat dijelaskan bahwa UU Perkawinan menyerahkan keputusan mengenai sahnya suatu perkawinan berdasarkan ajaran agamanya masing-masing. Tetapi faktanya bagi masing-masing agama tidak bisa dalam mengesahkan perkawinan beda agama dengan pengecualian salah satu dari pasangan mau untuk berpindah agama mengikuti salah satu pasangannya, namun hal ini dapat disebut sebagai penyimpangan agama atau sekedar tipu daya untuk dapat melangsungkan perkawinan.

Begitu juga dengan masalah terkait kedudukan buah hati yang dilahirkan. Menurut hukum, buah hati yang lahir dari perkawinan beda agama tetap ditetapkan sah jika perkawinan tersebut disahkan oleh agama dan dicatatkan di Kantor Catatan Sipil, karena anak yang sah menurut UU Perkawinan pasal 42 yaitu anak yang lahir dari perkawinan yang sah berdasarkan pasal 2 ayat (2), tetapi jika 
Volume 2 Nomor 2, Desember 2019

E-ISSN : 2655-7347

perkawinan beda agama dinyatakan tidak sah maka anak yang dilahirkan dianggap sebagai anak hasil luar kawin dan hanya mempunyai hubungan keperdataan dengan ibunya dan kerabat ibunya saja. Selepas dari masalah status anak, adanya akibat yang akan timbul yaitu mengenai warisan. Jika seorang suami beragama Islam, dan Isteri serta anak-anaknya mengikuti agama Katolik maka, sudah tentu menjadi rintangan untuk seorang suami untuk memberikan harta warisannya kepada istri maupun anaknya. Hukum kewarisan Islam meyatakan bahwa seseorang dapat terhalang untuk mendapatkan warisan atau menjadi ahli waris karena perbedaan agama, hal ini didasari pada hadis Rasulullah, Rowahu Buchori dan Muslim yang berarti ; “Orang Islam tidak mewaris harta orang kafir dan orang kafir tidak mewaris harta orang Islam.”

Jika perkawinan mereka diambang perceraian atau perpisahan yang pasti akan timbul penyelesaian akan hak dan kewajiban bagi pasangan suami istri serta buah hati jika terciptanya keturunan. Penyelesaian perceraian pada perkawinan beda agama sangat rumit, seperti halnya pada kasus perkawinan yang penulis teliti yaitu seorang pria beragama Islam menikahi wanita beragama Katolik, pasangan tersebut dapat melangsungkan pekawinan karena adanya penetapan pengadilan dan kemudian perkawinannya dapat dicatatkan ke KCS. Yang dipertanyakan, bagaimana proses perceraian yang sah bagi keduanya. Tentunya UU Perkawinan tidak mengatur secara khusus mengenai perkawinan beda agama. Permasalahan perkawinan beda agama hanya berpatok pada pasal 2 ayat (1) dan jika perkawinan beda agama timbul suatu perceraian, pertama yang harus dibahas adalah agama dari pihak suami. Apabila dalam agama Islam suatu perkawinan tidak dicatatkan di KUA maka perkawinan tersebut dianggap sebagai perkawinan siri. Kawin siri tidak diatur secara hukum, serta perkawinan tersebut 
Volume 2 Nomor 2, Desember 2019

E-ISSN : 2655-7347

tidak memiliki pengakuan yang sah dan tidak adanya perlindungan hukum. Jika perkawinan beda agama dapat melangsungkan pemberkatan secara agama Katolik, maka perkawinan tersebut dapat dikatakan diakui oleh agama, namun hal ini sangat kecil kemungkinan karena Katolik tidak membenarkan perkawinan beda agama. Secara religi, perkawinan dinyatakan sebagai perjanjian yang sakral dan hanya dilakukan satu kali selama hidupnya, maka perceraian dilarang keras oleh Katolik kecuali ada izin yang dikeluarkan dari pihak Uskup dan harus melewati alur pengadilan.

Pendapat penulis diperkuat oleh pendapat Drs. Sugeng, MSi selaku Kepala Dinas Kependudukan dan Catatan Sipil Ngawi yang menyatakan Meskipun dengan adanya penetapan hakim yang meyatakan bahwa perkawinan beda agama disetujui, maka dari pihak Catatan Sipil akan menanyakan terlebih dahulu kepada pusat yaitu Departemen Dalam Negeri apakah perkawinan tersebut tetap boleh dicatatkan atau tidak. Mengenai status anak bagi pasangan beda agama, pihak Catatan Sipil tidak bisa mengeluarkan akta kelahiran, kami dapat mengeluarkan akta kelahiran dengan catatan bahwa yang tertera dalam akta perkawinan hanya ibu kandungnya jadi dianggap bahwa anak tersebut hasil luar kawin karena perkawinannya yang tidak sah. Untuk kasus perkawinan beda agama yang mendapat penetapan Pengadilan Negeri kami sebagai pihak dispendukcapil tidak secara langsung mencatatkan akta nikah tetapi harus menanyakan terlebih dahulu kepada pihak pusat yaitu Departemen Dalam Negeri bagaimana penyelesaiannya untuk kasus seperti ini. Jika pihak Catatan Sipil tetap mengeluarkan akta nikah bagi pasangan beda agama, hal ini pihak Catatan Sipil dapat dipersalahkan dan dikenai sanksi.

\section{PENUTUP}

\section{A. Kesimpulan}


Volume 2 Nomor 2, Desember 2019

E-ISSN : 2655-7347

Didalam artikel yang penulis susun dapat diberikan kesimpulan yang diperoleh dari permasalahan yang diangkat di dalam skripsi yang berjudul “Analisis Penetapan Pengadilan Negeri Surakarta No. 46/Pdt.P/2016/PN.Skt Terkait Perkawinan Beda Agama Ditinjau Berdasarkan Undang-Undang No. 1 Tahun 1974” sebagai berikut :

1. Permohonan ijin perkawinan antar agama dikabulkannya dengan melihat pertimbangan hakim yaitu dalam penetapan No. 46/Pdt.P/2016/PN.Skt, dengan mengeluarkan persetujuan permohonan perkawinan beda agama tersebut, hakim berpendapat bahwa ada kekosongan hukum karena tidak diaturnya secara tegas perkawinan beda agama di dalam Undang-undang. Hal ini menimbulkan berbagai penafsiran di dalam masyarakat karena pertimbangan hakim dalam memutuskan permohonan perkawinan beda agama ini bertentangan dengan apa yang sebenarnya sudah diatur di dalam Undang-undang Perkawinan Pasal 2 ayat (1) yang pada intinya menyebutkan sah sutu perkawinan jika dilaksanakan menurut hukum agama dan kepercayaan masing-masing. yang terpenting dalam hal ini Hakim tidak bisa menghindari suatu perkara dengan alasan tidak ada peraturan yang mengaturnya. Pihak Catatan Sipil tidak dapat mengeluarkan akta perkawinan bagi pasangan beda agama sesuai dengan amanah Undangundang. Meskipun dengan adanya penetapan hakim yang meyatakan bahwa perkawinan beda agama disetujui, maka dari pihak Catatan Sipil akan menanyakan terlebih dahulu kepada pusat yaitu Departemen Dalam Negeri apakah perkawinan tersebut boleh dicatatkan atau tidak. Jika pasangan beda agama tetap ingin melangsungkan perkawinan beda agama, dapat dilakukan di Luar Negeri yang kemudian setelah kembali di Indonesia, perkawinan tersebut dapat dicatatkan dan di keluarkan akta perkawinannya.

2. Suatu ikatan perkawinan pasti akan membawa akibat hukum, jika hal ini dihubungkan dengan perkawinan beda agama maka perkawinan beda agama akan membawa akibat juga terhadap pasangan itu sendiri 
Volume 2 Nomor 2, Desember 2019

E-ISSN : 2655-7347

maupun juga anak yang akan dilahirkan dari perkawinannya. Akibat yang ditimbulkan dapat terbagi menjadi aspek psikologi dan aspek yuridis. Aspek psikologi yang terjadi yaitu kehidupan rumah tangga menjadi memudar yang diakibatkan karena bedanya visi dan iman antara suami dan istri, terkait agama yang akan dianut oleh sang anak. Jika aspek yuridis yang terkandung yaitu anak yang sah menurut UU Perkawinan pasal 42 yaitu anak yang lahir dari perkawinan yang sah berdasarkan pasal 2 ayat (2), tetapi jika perkawinan beda agama dinyatakan tidak sah sehingga anak yang dilahirkan dianggap sebagai anak hasil luar kawin dan hanya mempunyai hubungan keperdataan dengan ibunya dan kerabat ibunya saja. Serta masalah kewarisan, menurut hukum Islam tidak dapat diterimanya warisan oleh ahli waris akibat adanya hubungan perkawinan beda agama.

\section{B. Saran}

Dilihat dari permasalahan yang telah penulis cantumkan dalam skripsi ini, penulis memberikan saran dalam penyelesaian permasalahan ini sebagai berikut :

Beragamnya putusan hakim yaitu menyetujui dan menolak terkait perkawinan beda agama, menyebabkan terjadinya ketidakpastian hukum. Bagi para hakim Pengadilan Negeri yang menangani perkara permohonan ijin perkawinan beda agama diharapkan dalam memberikan pertimbangan suatu penetapan mengacu atas dasar Undang-undang yang berlaku agar dapat dipertanggungjawabkan dalam memutuskan suatu perkara dan hal ini menyebabkan adanya kepastian hukum. Perkawinan merupakan salah satu hak asasi manusia yang mana hak asasi manusia ini dipunyai oleh setiap orang yang wajib dijamin oleh Negara, sehingga pemerintah harus dengan tegas Namun hal ini juga dapat didukung dengan dilakukannya revisi Undang-undang untuk mempertegas mengenai perkawinan beda agama dengan dibuatnya pernyataan yang mendukung didalam Peraturan Pemerintah, sehingga tidak ada lagi 


\section{Jurnal Hukzum Adigamẩ}

Volume 2 Nomor 2, Desember 2019

E-ISSN : 2655-7347

perbedaan antara hakim dalam memberikan penetapan terkait perkawinan beda agama. Bagi masyarakat yang dengan terpaksa hendak melakukan perkawinan beda agama sebaiknya maka diharapkan untuk lebih taat akan Undang-undang yang berlaku di Indonesia dan memperkuat serta taat akan hukum agamanya masing-masing.

\section{DAFTAR PUSTAKA}

\section{A. Buku}

Fajar, Mukti dan Yulianto Achmad. Dualisme Penelitian Hukum Normatif \& Empiris, Cetakan ke-4. (Yogyakarta: Pustaka Pelajar, 2017.)

Marzuki, Peter Mahmud. Pengantar Ilmu Hukum. (Jakarta: Kencana Prenada Media Group, 2014.)

Soerjono dan Mamudji. Penelitian Hukum Normatif: Suatu Tinjauan Singkat. (Jakarta: Rajawali Pers, 2011.)

Usman Adji, Sutiono. Kawin Lari dan Kawin Antar Agama. (Yogyakarta: Liberty Yogyakarta, 1989.)

\section{B. Peraturan Perundang-undangan}

Indonesia. Undang-undang No. 1 Tahun 1974 tentang Perkawinan . PP No. 9 Tahun 1975 tentang Pelaksanaan Undang-

Undang Nomor 1 Tahun 1974 Tentang Perkawinan . Kompilasi Hukum Islam . Undang-undang No. 24 Tahun 2013 tentang perubahan atas

Undang- undang No. 23 Tahun 2006 tentang Administrasi

Kependudukan 